\title{
PAWE⿺ SoBczyK
}

Uniwersytet Kardynała Stefana Wyszyńskiego

\section{OCHRONA DANYCH OSOBOWYCH JAKO ELEMENT PRAWA DO PRYWATNOŚCI}

\section{KonSTYTUCJONALIZACJA OCHRONY DANYCH OSOBOWYCH}

Problematyka ochrony danych osobowych w Polsce ma stosunkowo krótką historię ${ }^{1}$ W art. 51 Konstytucji Rzeczypospolitej Polskiej z dnia 2 kwietnia 1997 r. zostało sformułowane prawo do ochrony danych osobowych, na które składają się podstawowe zasady: wolności jednostki od ujawnienia informacji dotyczących jej osoby, kompetencji władz publicznych do pozyskiwania, gromadzenia i udostępniania informacji o obywatelach, prawo dostępu każdego mieszkańca Polski do dotyczących go dokumentów urzędowych i zbiorów danych, prawo żądania sprostowania informacji zawartych w zbiorach urzędowych dokumentów i zbiorach danych oraz prawo żądania usunięcia informacji zawartych w zbiorach urzędowych dokumentów i zbio-

\footnotetext{
${ }^{1}$ Na temat gwarancji prawa do ochrony danych osobowych i prawa do prywatności w polskim konstytucjonalizmie przed wejściem w życie Konstytucji Rzeczypospolitej Polskiej z dnia 2 kwietnia 1997 r. pisała m.in. J. BArciak, Prawo do prywatności, Warszawa 2004, s. 157-160. Warto odnotować na wstępie rozważań, iż istnienie prawa do prywatności w polskim porządku prawnym zostało potwierdzone m.in. w orzeczeniu Sądu Najwyższego z dnia 8 kwietnia 1994 r., który koncepcję ochrony dóbr osobistych (art. 23 i 24 k.c.) odniósł do sfery życia prywatnego i sfery intymności (III ARN 18/94).
} 
rach danych ${ }^{2}$. Konstytucyjne zasady zostały powtórzone i rozwinięte w ustawie z dnia 29 sierpnia 1997 r. o ochronie danych osobowych ${ }^{3}$. Nie oznacza to jednak, iż wcześniej nie istniał problem ochrony danych osobowych. Doktryna i orzecznictwo rozstrzygały kwestie dotyczące ochrony jednostki ze względu na dotyczące jej dane osobowe na gruncie art. 23 i 24 k.c. ${ }^{4}$ Konieczność ochrony danych osobowych pojawiła się wraz z rozwojem technik informacyjnych i zagwarantowaniem - również na płaszczyźnie konstytucyjnej i ustawowej - prawa do informacji. Zdaniem M. Safjana istnieją dwa główne powody tworzenia mechanizmów ochrony danych osobowych. Pierwszym z nich jest nieskuteczność tradycyjnych mechanizmów ochrony prywatności, które były wykorzystywane na gruncie prawa cywilnego i prawa karnego. Drugim natomiast uznanie środków publicznoprawnych za podstawowy środek ochrony danych osobowych ${ }^{5}$. Konstytucjonalizacja ochrony danych osobowych przyczyniła się także do podniesienia rangi zagadnienia za względu na miejsce, jakie w hierarchii źródeł prawa zajmuje w polskim systemie prawnym ustawa zasadnicza. Ponadto wpłynęła ona pozytywnie, co można ocenić z perspektywy ponad dziesięciu lat,

${ }^{2}$ Por. art. 51 Konstytucji Rzeczypospolitej Polskiej z dnia 2 kwietnia 1997 r., Dz.U. $\mathrm{Nr} 78$, poz. 483 ze zm. Przepisy dotyczące prawa do ochrony danych osobowych stanowią na gruncie polskiego konstytucjonalizmu istotne novum.

3 Ustawa z dnia 29 sierpnia 1997 r. o ochronie danych osobowych, tekst jednolity Dz.U. z 2002 r. Nr 101, poz. 926 ze zm. Polska ustawa o ochronie danych osobowych jest implementacją dyrektywy Parlamentu Europejskiego i Rady z dnia 24 października $1995 \mathrm{r}$. w sprawie ochrony osób fizycznych w zakresie przetwarzania danych osobowych oraz swobodnego przepływu tych danych (95/46/WE). Celem tej dyrektywy jest zapewnienie jednolitego minimalnego poziomu ochrony prywatności osób fizycznych w zakresie przetwarzania danych osobowych oraz zapewnienie swobodnego przepływu danych między krajami członkowskimi Unii Europejskiej.

4 Niemiecka nauka prawa konstytucyjnego prawo do „informacyjnego samookreślenia się" wyprowadza z prawa osobistości. Podobnie w konstytucjach, w których nie zagwarantowano wprost prawa do ochrony danych osobowych, konstytucyjna ochrona danych osobowych jednostki jest realizowana poprzez interpretację norm dotyczących ochrony dóbr osobistych lub prywatności.

5 Por. M. SAFJAN, Prawo do prywatności i ochrona danych osobowych w spoleczeństwie informatycznym, «PiP» 57.6 (2002), s. 7. 
na prawodawstwo w omawianym zakresie ${ }^{6}$. Na system źródeł związanych z ochroną danych osobowych, obok Konstytucji RP i ustawy o ochronie danych osobowych, składają się także wydawane na jej podstawie przez Ministra Spraw Wewnętrznych i Administracji rozporządzenia: z dnia 22 kwietnia 2004 r. w sprawie wzorów imiennego upoważnienia i legitymacji służbowej inspektora Biura Generalnego Inspektora Ochrony Danych Osobowych ${ }^{7}$, z dnia 29 kwietnia 2004 r. w sprawie dokumentacji przetwarzania danych osobowych oraz warunków technicznych i organizacyjnych, jakim powinny odpowiadać urządzenia i systemy informatyczne służące do przetwarzania danych osobowych ${ }^{8}$ oraz z dnia 29 kwietnia 2004 r. w sprawie wzoru zgłoszenia zbioru do rejestracji Generalnemu Inspektorowi Danych Osobowych ${ }^{9}$. Podniesienie ochrony danych osobowych do rangi konstytucyjnej posiada niewątpliwie największe znaczenie ze względu na wpływ, jaki wywiera na sytuację prawną jednostki. Taki bowiem był cel ustrojodawcy, który wśród wolności i praw osobistych sformułował prawo do prywatności oraz powiązane z nim prawo do ochrony danych osobowych ${ }^{10}$.

6 Por. G. KoKsanowicz, Ochrona danych osobowych w świetle Konstytucji oraz Ustawy o ochronie danych osobowych, [w:] Konstytucyjny ustrój państwa. Ksiega jubileuszowa Profesora Wiesława Skrzydty, red.: T. Bojarski, E. Gdulewicz, J. SzRENIAWSKI, Lublin 2000, s. 93.

7 Dz.U. Nr 94, poz. 923.

8 Dz.U. Nr 100, poz. 1024.

9 Dz.U. Nr 100, poz. 1025.

${ }^{10}$ Podobne znaczenie posiada ustawa o ochronie danych osobowych i działalność Generalnego Inspektora Ochrony Danych Osobowych: „W obliczu postępującej informatyzacji życia społecznego, rozwoju nowych technologii i globalizacji, funkcjonowanie jednostki w strukturze społeczeństwa staje się w zasadzie niemożliwe bez szerokiej ingerencji w sferę prywatności. Każda osoba, której prawa zostaną naruszone może jednak zwrócić się o zbadanie procesu przetwarzania jej danych, a rozpatrywanie skarg i przeprowadzanie czynności kontrolnych mających na celu zbadanie, czy nie doszło do naruszeń ustawy o ochronie danych osobowych jest jednym z zadań Generalnego Inspektora". M. KrasińSKA, S. MizereK, $A B C$ wybranych zagadnień ustawy o ochronie danych osobowych, Warszawa 2007, s. 6. 


\section{KONSTYTUCYJNE PRAWA OSÓB, KTÓRYCH DANE DOTYCZĄ}

Na podstawie art. 51 Konstytucji Rzeczypospolitej Polskiej z dnia 2 kwietnia 1997 r. na prawo do ochrony danych osobowych, stanowiące element prawa do prywatności, składają się szczegółowe uprawnienia osób, których dane dotyczą. Zalicza się do nich: wolność jednostki od ujawnienia informacji dotyczących jej osoby (art. 51 ust. 1), prawo dostępu każdego mieszkańca Polski do dotyczących go dokumentów urzędowych i zbiorów danych (art. 51 ust. 3), prawo żądania sprostowania oraz usunięcia informacji nieprawdziwych, niepełnych lub zebranych w sposób sprzeczny z ustawą (art. 51 ust. 4).

Wolność jednostki od ujawnienia informacji dotyczących jej osoby jest określana przez doktrynę jako prawo lub zasada samodzielnego decydowania każdej osoby o ujawnieniu dotyczących jej informacji. Prawo to (zasada) odnosi się do wszelkich informacji dotyczących jednostki, natomiast zobowiązanie jednostki do ujawnienia informacji dotyczących jej osoby mają zawsze charakter wyjątkowy oraz muszą mieć ustawową podstawę ${ }^{11}$.

Przepis art. 51 ust. 1 wiąże się z ujawnianiem ,wszelkich informacji dotyczących każdego z przejawów nie tylko ściśle osobistego, lecz również publicznego zachowania się jednostki; jej szczególnym wyrazem jest wolność od ujawniania organom władzy publicznej swojego światopoglądu, przekonań religijnych lub wyznania (art. 53 ust. 7)"12. Warto zwrócić uwagę, iż zdaniem P. Sarneckiego wolność od ujawniania organom władzy publicznej swojego światopoglądu, przekonań religijnych lub wyznania jest elementem ochrony danych osobowych. Zgodnie $\mathrm{z}$ prezentowanym $\mathrm{w}$ niniejszym opracowaniu stanowiskiem gwarancje zawarte w art. 53 ust. 7 Konstytucji są także rozwinięciem i uszczegółowieniem prawa do prywatności, na podobnych zasadach jak ochrona danych osobowych. Wskazuje to na szczególny charakter

11 J. Barta, P. Fajgielski, R. Markiewicz, Ochrona danych osobowych. Komentarz, Kraków 2007, s. 115.

12 P. Sarnecki, Art. 51, [w:] Konstytucja Rzeczypospolitej Polskiej. Komentarz, III, red. L. GARLICKI, Warszawa 2003, s. 1-2. 
prawa do prywatności oraz - w kontekście prowadzonych rozważań - jest potwierdzeniem tezy, iż ochrona danych osobowych jest konsekwencją prawa do prywatności. Analizowana wolność jednostki od ujawnienia informacji dotyczących jej osoby oznacza także zakaz podejmowania prób przez określone w ustawach podmioty uzyskiwania tego typu informacji poprzez indagację osób.

W tej szczegółowej gwarancji dotyczącej jednostki pojawia się zasada legalizmu, sformułowana w sposób ogólny w art. 7 Konstytucji: „Organy władzy publicznej działają na podstawie i w granicach prawa”. Zgodnie z tą zasadą dla wszystkich obowiązków informacyjnych człowieka wymagana jest w Polsce podstawa ustawowa. I. Lipowicz zwróciła uwagę, że „Obowiązek informacyjny może być nakładany bezpośrednio lub pośrednio. Złamaniem zasady konstytucyjnej będzie więc również na przykład uzależnienie wydania decyzji budowlanej lub uzyskania zasiłku od uzyskania informacji, co do których nie istnieje podstawa ustawowa. Także informacja osobowa imigrantów, uchodźców starających się o azyl w Polsce będzie musiała mieć odpowiednią podstawę ustawowa - np. w ustawie o cudzoziemcach. Obowiązek informacyjny może być konkretyzowany w aktach niższego rzędu (rozporządzeniach), nigdy jednak nie może być oparty wyłącznie na nich"'13. Ustawowa podstawa w zakresie określania obowiązku ujawnienia przez jednostkę informacji jej dotyczących nie oznacza braku kontroli nad konstytucyjnością ustaw. Podstawowym obowiązkiem Trybunału Konstytucyjnego jest, na mocy art. 188 pkt. 1, orzekanie w sprawach zgodności ustaw z Konstytucją, w tym także - co oczywiste - ustaw określających zasady ochrony danych osobowych. Ustrojodawca chroni w ten sposób jednostkę przed niewłaściwym działaniem ustawodawcy, to jest takim, które narusza konstytucyjne gwarancje prawa do prywatności i ochrony danych osobowych.

W art. 51 ust. 3 Konstytucji RP ustrojodawca w sposób ogólny zagwarantował dostęp jednostki do dokumentów urzędowych, przez co na gruncie prawa konstytucyjnego należy rozumieć „świadectwo

13 I. Lipowicz, Art. 51 I, [w:] Konstytucje Rzeczypospolitej oraz komentarz do Konstytucji RP z 1997 roku, red. J. Boć, Wrocław 1998, s. 99. 
odpowiednich działań władz publicznych"14, oraz do zbiorów danych, które są ,zestawami informacji, uzyskanymi przez dany czynnik władzy publicznej”"15. Szczegółowo dostęp do dokumentów urzędowych i zbiorów danych jeszcze przed wejściem w życie Konstytucji z dnia 2 kwietnia 1997 r. określały różne ustawy. W tym sensie gwarancje ustawy o ochronie danych osobowych uznać należy za ogólne. Prawo dostępu jednostki do dotyczących jej urzędowych dokumentów i zbiorów danych jest przejawem kontroli nad gromadzonymi informacjami. Z przepisu wynika, że jednostka nie może domagać się dostępu do dokumentów i zbiorów danych, które nie mają charakteru urzędowego. Dotyczyć to będzie przede wszystkim dokumentów i zbiorów prywatnych, nawet w przypadku, gdy będą one nastawione na gromadzenie informacji dotyczących danej osoby.

Sformułowane w art. 51 ust. 4 Konstytucji RP prawo żądania sprostowania oraz usunięcia informacji nieprawdziwych, niepełnych lub zebranych w sposób sprzeczny z ustawą jest urzeczywistnieniem prawa kontroli na gruncie ochrony danych osobowych. Warto zwrócić uwagę, że ustrojodawca dysponentem prawa zapisanego w omawianym przepisie czyni każdego, kto stwierdzi, że informacje dotyczące go są niepełne lub błędne. Cechą charakterystyczną sformułowań zawartych w ust. 4 omawianego przepisu jest wyposażenie jednostki w prawo do żą d a n i a (podkreślenie P.S.) sprostowania i usunięcia, a nie prawo do sprostowania i usunięcia. Może to, ale nie musi, świadczyć o osłabieniu i uznaniowym charakterze gwarancji ${ }^{16}$.

W rozdziale 4 ustawy z dnia 29 sierpnia 1997 r. o ochronie danych osobowych zostały zawarte uprawnienia osoby, której dane dotyczą, będące gwarancją konstytucyjnego prawa do ochrony danych osobo-

14 P. SARNeCKI, Art. 51, cit., s. 5.

15 P. SARneCKI, Art. 51, cit., s. 5.

16 Odmiennego zdania są J. Barta, P. Fajgielski, R. Markiewicz, op. cit., s. 115. Piszą oni: „należy zaznaczyć, że wprawdzie Konstytucja nie stanowi wprost o prawie do sprostowania czy usunięcia, ale o ,prawie do żądania” sprostowania i usunięcia, to jednak nie powinno stanowić argumentu na rzecz osłabienia prawa i uznania, że jego respektowanie (przez dysponenta informacji) ma w jakiejś mierze uznaniowy charakter". 
wych. Ustawa jest bowiem realizacją konstytucyjnego nakazu sformułowanego w art. 51 ust. 5 określenia zasad i trybu gromadzenia oraz udostępniania informacji. Warto zaznaczyć, iż ,Uprawnienia przyznane na podstawie przepisów ustawy o.d.o., w tym także zamieszczonych w rozdziale 4, mają charakter autonomiczny względem uprawnień przysługujących podmiotowi danych na podstawie przepisów innych dziedzin prawa, zwłaszcza przepisów k.c. regulujących ochronę dóbr osobistych" 17 . Ponadto przepisy te są rozwinięciem zasad przetwarzania danych osobowych, sformułowanych przez ustawodawcę w art. 23-26, pod kątem uprawnień osoby, której dane osobowe dotyczą ${ }^{18}$.

Bardzo szeroki katalog uprawnień zawartych w rozdziale 4 ustawy jest przez doktrynę różnie klasyfikowany ${ }^{19}$. J. Barta, P. Fajgielski,

17 A. Drozd, Ustawa o ochronie danych osobowych. Komentarz. Wzory pism i przepisy, Warszawa 2008, s. 216.

18 Por. J. Barta, P. Fajgielski, R. Markiewicz, op. cit., s. 570.

19 Na podstawie art. 32 ust. 1 ustawy do działań tych zalicza się prawo do: „1) uzyskania wyczerpującej informacji, czy taki zbiór istnieje, oraz do ustalenia administratora danych, adresu jego siedziby i pełnej nazwy, a w przypadku gdy administratorem danych jest osoba fizyczna - jej miejsca zamieszkania oraz imienia i nazwiska, 2) uzyskania informacji o celu, zakresie i sposobie przetwarzania danych zawartych w takim zbiorze, 3) uzyskania informacji, od kiedy przetwarza się w zbiorze dane jej dotyczące, oraz podania w powszechnie zrozumiałej formie treści tych danych, 4) uzyskania informacji o źródle, z którego pochodzą dane jej dotyczące, chyba że administrator danych jest zobowiązany do zachowania w tym zakresie tajemnicy państwowej, służbowej lub zawodowej, 5) uzyskania informacji o sposobie udostępniania danych, a w szczególności informacji o odbiorcach lub kategoriach odbiorców, którym dane te są udostępniane, 5a) uzyskania informacji o przesłankach podjęcia rozstrzygnięcia, o którym mowa w art. 26a ust. 2, 6) żądania uzupełnienia, uaktualnienia, sprostowania danych osobowych, czasowego lub stałego wstrzymania ich przetwarzania lub ich usunięcia, jeżeli są one niekompletne, nieaktualne, nieprawdziwe lub zostały zebrane z naruszeniem ustawy albo sąjuż zbędne do realizacji celu, dla którego zostały zebrane, 7) wniesienia, w przypadkach wymienionych w art. 23 ust. 1 pkt 4 i 5, pisemnego, umotywowanego żądania zaprzestania przetwarzania jej danych ze względu na jej szczególną sytuację, 8) wniesienia sprzeciwu wobec przetwarzania jej danych w przypadkach, wymienionych w art. 23 ust. 1 pkt 4 i 5, gdy administrator danych zamierza je przetwarzać w celach marketingowych lub wobec przekazywania jej danych osobowych innemu administratorowi danych, 9) wniesienia 
R. Markiewicz wyróżniają uprawnienia informacyjne zawarte w art. 32 ust. 1 pkt 1-5a oraz $\mathrm{w}$ art. 33, uprawnienia korekcyjne zapisane $\mathrm{w}$ art. 32 ust. 1 pkt 6 i 9 oraz w art. 35, a także uprawnienia zakazowe sformułowane w art. 32 ust. 1 pkt 7-8 oraz w art. 35. A. Drozd, przyjmując jako kryterium naruszenie przepisów lub usprawiedliwionych interesów podmiotu danych przy ich przetwarzaniu, wyróżnił uprawnienia informacyjne zawarte $\mathrm{w}$ art. 32 ust. 1 pkt 1-5a oraz uprawnienia rektyfikacyjne, których przesłanką zaktualizowania się jest naruszenie przepisów lub usprawiedliwionych interesów podmiotu danych w związku z przetwarzaniem ${ }^{20}$.

Porównując szczegółowe uprawnienia jednostki dotyczące danych osobowych zawarte w art. 51 Konstytucji RP z postanowieniami rozdziału 4 ustawy o ochronie danych osobowych należy stwierdzić, iż uprawnienia pokrywają się, chociaż zostały one w różny sposób sformułowane.

\section{ZWIĄZEK OCHRONY DANYCH OSOBOWYCH Z PRAWEM DO PRYWATNOŚCI}

Z przepisów polskiej ustawy zasadniczej wynika, iż prawo do ochrony danych osobowych jest pochodną prawa do prywatności ${ }^{21}$. Za pomocą art. 47 Konstytucji RP ustrojodawca chroni życie prywatne, rodzinne i osobiste w następujący sposób: „Każdy ma prawo do ochrony prawnej życia prywatnego, rodzinnego, czci i dobrego imienia oraz do decydowania o swoim życiu osobistym"22. W kolejnych przepisach ustawy

do administratora danych żądania ponownego, indywidualnego rozpatrzenia sprawy rozstrzygniętej z naruszeniem art. 26a ust. 1".

${ }^{20}$ Por. A. DrozD, op. cit., s. 216-217.

${ }^{21}$ M. SAfJan, op. cit., s. 6 pisze m.in.: „Problem ochrony prawa do prywatności, zwłaszcza ochrony danych osobowych i autonomii informacyjnej, pojawia się na etapie, w którym zagrożenie prywatności osiaga apogeum. Prywatność w tym oto znaczeniu, w jakim mówimy o autonomii informacyjnej jednostki, zaczyna podlegać ochronie na takiej zasadzie, na jakiej chroni się ginący gatunek flory lub fauny".

${ }^{22}$ Nie podejmując szczegółowych rozważań na temat pojęcia prawa do prywatności na gruncie Konstytucji RP należy wskazać, że jego przedmiotem jest życie prywatne, rodzinne i osobiste. Są to pojęcia, których zakres nie jest ściśle rozgraniczony. Życie 
zasadniczej rozwija oraz doprecyzowuje gwarancje ochrony prawa do prywatności zapisanego w sposób ogólny ${ }^{23}$. W art. 48 ust. 1 i art. 53 ust. 3 ustrojodawca chroni prawo rodziców do zapewnienia dzieciom wychowania i nauczania moralnego i religijnego zgodnie ze swoimi przekonaniami, w art. 49 chroni wolność i ochronę tajemnicy komunikowania się, w art. 50 zapewnia nienaruszalność mieszkania, a w art. 51 zapewnia możliwość uchylenia się od odkrywania życia prywatnego, rodzinnego i osobistego poprzez ujawnianie informacji dotyczących osoby. Do przepisów konstytucyjnych, za pomocą których ustrojodawca chroni prywatność i niektóre jej aspekty można także zaliczyć możliwość wyłączenia jawności rozprawy ze względu na ochronę życia prywatnego stron lub inny ważny interes prywatny (art. 45 ust. 2), zakaz zobowiązania jednostki przez organy władzy publicznej do ujawnienia swojego światopoglądu, przekonań religijnych lub wyznania (art. 53 ust. 7) oraz ochronę konsumentów, użytkowników i najemców przed działaniami zagrażającymi ich prywatności (art. 76) ${ }^{24}$.

Związek, jaki istnieje między prawem do prywatności a ochroną danych osobowych można określić jako związek materialny. Ochrona prywatności w dużym stopniu jest zależna od ochrony danych osobowych, które dotyczą jednostki. W świetle orzecznictwa Trybunału Konstytucyjnego prawo do ochrony danych osobowych zapisane w art.

prywatne jest uznawane za przeciwieństwo życia publicznego, obejmuje zatem relacje z rodzina, przyjaciółmi i znajomymi. Życie rodzinne to relacje do współmałżonka oraz osób pozostających w stosunku pokrewieństwa i powinowactwa. Sferę życia rodzinnego jako wymiar prawa do prywatności należy interpretować w kontekście art. 18, w którym ustrojodawca potwierdził, że „małżeństwo jako związek kobiety i mężczyzny, rodzina, macierzyństwo i rodzicielstwo znajdują się pod ochroną i opieką Rzeczypospolitej Polskiej”. Ostatni, konstytucyjny wymiar prawa do prywatności, stanowi życie osobiste, na które skała się m.in. sposób spędzania wolnego czasu, rozwijane zainteresowania oraz decyzja o wyborze miejsca zamieszkania.

23 Prawa zapisane w art. 48-51 Konstytucji RP za gwarancje ochrony prawa do ochrony prywatności uważa m.in. L. SzYMAŃsKa, Prawo do ochrony życia prywatnego na podstawie art. 47, 49-51 Konstytucji RP-wybrane zagadnienia, [w:] Polska wobec europejskich standardów praw człowieka, red. T. JASUDOwICZ, Toruń 2001, s. 139.

${ }_{24}$ Por. J. Braciak, Prawo do prywatności, Warszawa 2004, s. 161-164. 
51 Konstytucji jest pewnego rodzaju wyspecjalizowaną konstrukcją, która służy ochronie tych samych wartości, które zostały sformułowane $\mathrm{w}$ art. $47^{25}$. Konstrukcja ta jest $\mathrm{w}$ orzecznictwie Trybunału prezentowana w następujący sposób: ,prawo do prywatności, statuowane w art. 47, zagwarantowane jest m.in. w aspekcie ochrony danych osobowych, przewidzianej w art. 51. Ten ostatni, rozbudowany przepis, odwołując się aż pięciokrotnie do warunku legalności - expressis verbis w ust. 1, 3, 4 i 5 oraz pośrednio przez powołanie się na zasadę demokratycznego państwa prawnego w ust. 2 - stanowi też konkretyzację prawa do prywatności w aspektach proceduralnych"26.

„W doktrynie na ogół przyjmuje się, że prywatność odnosi się m.in. do ochrony informacji dotyczących danej osoby i gwarancji pewnego stanu niezależności, w ramach której człowiek może decydować o zakresie i zasięgu udostępniania i komunikowania innym osobom informacji o swoim życiu. ${ }^{\text {27 }}$. Dlatego też można stwierdzić, iż prawo do ochrony danych osobowych nawiązuje i rozwija prawo do prywatności, jest jego konsekwencją. Przy wykładni uregulowań szczegółowych dotyczących prywatności należy odnosić się do art. 47. Odrębne uregulowanie prawa do ochrony danych osobowych wynika $z$ dostrzegania przez ustrojodawcę niebezpieczeństw dla jednostki i jednocześnie chęci zabezpieczenia tej wolności. Słusznie zwraca się uwagę, że na koncepcję prawa do prywatności składają się zasady i reguły, które dotyczą różnych sfer życia ${ }^{28}$.

25 Por. P. SARnecki, Art. 47, [w:] Konstytucja Rzeczypospolitej Polskiej, cit., s. 4.

26 Orzeczenie Trybunału Konstytucyjnego U5/97, OTK 1998/4/46. J. BARTA, P. Fajgielski, R. Markiewicz, op. cit., s. 116 piszą natomiast, że ,rozważając ochronę danych osobowych na gruncie Konstytucji RP nie sposób pominąc prawa do prywatności”.

27 Orzeczenie TK U5/97. Prawo do prywatności jest prawem trzeciej generacji, uregulowanym w wielu konstytucjach współczesnych państw oraz w ustawodawstwie zwykłym. Na jego treść składa się przede wszystkim prawo jednostki do prawnej ochrony określonych sfer życia oraz prawo do decydowania o życiu osobistym.

${ }_{28}$ Por. K. WyGoda, Ochrona danych osobowych i prawo do informacji o charakterze osobowym, [w:] Prawa i wolności obywatelskie, red.: B. BanaszaK, A. Preisner, Warszawa 2002, s. 400 i n. 
Analizując relacje między konstytucyjnym prawem do prywatności a prawem do ochrony danych osobowych należy wziąć pod uwagę ich miejsce w systematyce ustawy zasadniczej. Oba prawa słusznie zostały zaliczone przez ustrojodawcę do kategorii wolności i praw osobistych, a zatem takich, dla których podstawą nie jest wola państwa wyrażona przez podmioty stanowiące ustawę zasadniczą, ale przyrodzona godność człowieka.

P. Sarnecki pisze, że ,gwarantując prawo do prywatności, nie może konstytucja - w sposób generalny - pozwalać organom władzy publicznej ani na dokumentowanie dla własnych celów tzw. danych osobowych, czyli informacji o osobowych właściwościach (indywidualnych cechach) konkretnych jednostek, ani też zezwalać im na penetrowanie i dokumentowanie zachowań osób prywatnych, ani też w końcu zmuszać te osoby do ujawniania swych cech, właściwości oraz swego osobistego postępowania i tu już nie tylko wobec wspomnianych organów, ale wobec kogokolwiek" ${ }^{29}$. Jeżeli natomiast zbiory już istnieją jednostce przysługuje prawo dostępu do takich danych, wnoszenia sprostowań oraz ewentualnie żądania usunięcia pewnych danych. Wynika to z godności osoby ludzkiej, natury praw osobistych, prawa do prywatności oraz zasady demokratycznego państwa prawa.

Nie bez znaczenia dla omawianego związku ochrony danych osobowych z prawem do prywatności jest konstytucyjny charakter prawa do prywatności. Dominującą pozycję w konstytucyjnym systemie ochrony praw człowieka posiada relacja wertykalna między państwem a jednostką. W związku z tym dane osobowe jednostki są chronione przede wszystkim przed niewłaściwym działaniem organów władzy publicznej. Zostało to potwierdzone przez przepis art. 51 ust. 2: „Władze publiczne nie moga pozyskiwać, gromadzić i udostępniać innych informacji o obywatelach niż niezbędne w demokratycznym państwie prawnym". Relacja horyzontalna, obejmująca relacje między jednostkami, ma na gruncie prawa konstytucyjnego znaczenie drugorzędne. Ochrona prywatności, w tym danych osobowych, na gruncie ustawodawstwa zwykłego ma przede wszystkim charakter roszczeń

29 P. SARNeCKI, Art. 51, cit., s. 3. 
o zaniechanie tzn. ,niewkraczanie w sferę spraw intymnych, osobistych, rodzinnych, pozostawienie jednostki ,w spokoju” i nieujawnianie informacji dotyczących tej właśnie sfery życia" ${ }^{30}$.

Konstytucyjna gwarancja prawa do prywatności ma fundamentalne znaczenie w procesie stosowania przepisów chroniących dane osobowe. Ustrojodawca zezwolił bowiem na przetwarzanie danych osobowych, które ogranicza prawo do prywatności (art. 51), chroniąc jednocześnie prawo do prywatności obejmujące życie prywatne, rodzinne i osobiste (art. 47). Konstrukcja przepisów art. 47 i 51 wydaje się w tym zakresie być sprzeczna z koncepcją racjonalnego ustrojodawcy. Zakładając jednak, że prawo do prywatności obejmuje swobodę decydowania o własnej prywatności, w tym swobodę dysponowania danymi dotyczącymi osoby, której one dotyczą, konstytucyjna sprzeczność ma charakter pozorny. Ustrojodawca gwarantując prawo do prywatności zakłada, że jednostka korzystając ze swojego prawa będzie decydowała o tym komu i jakie dane osobowe przekaże. Problemem w tym zakresie są jednak przepisy rangi ustawowej, na podstawie których jednostka może zostać zobowiązana do udostępnienia danych osobowych, skoro na podstawie art. 51 ust. 1 ,Nikt nie może być obowiązany inaczej niż na podstawie ustawy do ujawnienia informacji dotyczących jego osoby”. W przypadku gdyby ustawodawca złamał ogólne zasady dotyczące ochrony danych osobowych i prawa do prywatności, w świetle obowiązujących przepisów Konstytucji, ostateczny głos należeć będzie do Trybunału Konstytucyjnego, który może zbadać konstytucyjność takiego unormowania, które stanowi naruszenie aspektu proceduralnego (formalnego), czyli ustawowej rangi przedmiotowego aktu normatywnego oraz materialnego, czyli spełnienia konstytucyjnych przesłanek przyjętego ograniczenia w zakresie ujawnienia informacji dotyczących osoby. Jak stwierdził Trybunał Konstytucyjny „o ile sama ustawowa ranga unormowania ograniczeń statusu jednostki nie wystarcza dla uznania ich merytorycznej zasad-

${ }^{30}$ M. JAGIELSKI, Konstytucjonalizacja ochrony prywatności, [w:] Konstytucjonalizm a doktryny polityczno-prawne. Najnowsze kierunki badań, red. R.M. MaŁaJny, Katowice 2008, s. 275. 
ności, która podlega weryfikacji w zakresie spełnienia przesłanek materialnych art. 31 ust. 3, o tyle a contrario: brak zachowania ustawowej formy dla ograniczeń wolności i praw prowadzić musi do dyskwalifikacji danego unormowania, jako sprzecznego ze wskazaną normą art. 31 ust. 3 konstytucji" 31 .

Warto na koniec rozważań w tym punkcie odnotować, iż nie wszyscy autorzy podzielają zaprezentowany pogląd. Zdaniem J. Barty i R. Markiewicza ochrona danych osobowych nie łączy się z prawem do prywatności, skoro ustrojodawca obydwu tym kwestiom poświęcił odrębne przepisy. „Pomiędzy ochroną prawa do prywatności - piszą - (występującą na płaszczyźnie prawa konstytucyjnego oraz w ramach powszechnych dóbr osobistych) a ochroną danych osobowych (dostrzeganą w nowej Konstytucji RP, a szczegółowo ujmowaną w omawianej w tej opinii ustawie z 1997 r.) zachodzi stosunek krzyżowania się w tym tylko sensie, że istnieją zachowania, które mogą równolegle naruszać ochronę przewidzianą w obu rozważanych płaszczyznach. Są to przy tym reżimy wzajemnie niezależne"32. W związku z powyższym przetwarzanie danych osobowych w określonych sytuacjach może wiązać się z naruszeniem prawa do prywatności, a naruszenie prawa do prywatności z ochroną danych osobowych. Zdaniem cytowanych Autorów w przypadku przetwarzania danych osobowych, które narusza prawo do prywatności występuje ochrona kumulowana, przewidziana w art. 23 k.c., zgodnie z którym dobra osobiste ,pozostają pod ochroną prawa cywilnego, niezależnie od ochrony przewidzianej w innych przepisach"33. A zatem stosowanie przepisów Kodeksu cywilnego nie wyklucza stosowania przepisów ustawy o ochronie danych osobowych, skoro sam ustawodawca przewidział taką sytuację. J. Barta i R. Markiewicz nie dostrzegają także związku między prawem do prywatności a ochroną danych osobowych na gruncie przepisów Konstytucji RP w relacji lex specialis - lex generalis. Ich zdaniem

${ }^{31}$ Orzeczenie TK U 5/97.

32 J. Barta, R. Markiewicz, Prawo do prywatności wspoleczeństwie informatycznym, «Ethos» 45-46 (1999), s. 380.

33 Por. J. Barta, R. Markiewicz, op. cit., s. 381. 
brzmienie i systematyka przepisów nie pozwalają na takie stwierdzenie, chociaż orzecznictwo Sądu Najwyższego pozwala zaobserwować tendencję do rozszerzającego interpretowania zakresu ochrony, która wynika z art. 23 i art. 24 k.c. We wspomnianym orzeczeniu Sąd Najwyższy stanął na stanowisku tzw. otwartego katalogu dóbr osobistych, pozwalając na włączenie do katalogu dóbr związanych z życiem prywatnym, rodzinnym oraz ze sferą intymności ${ }^{34}$.

\section{Demokratyczne państWo PRAWA GWARANTEM PRAWA} DO PRYWATNOŚCI I OCHRONY DANYCH OSOBOWYCH

Obok klasycznej triady wartości - godności, wolności i równości - na gruncie Konstytucji Rzeczypospolitej Polskiej z dnia 2 kwietnia 1997 r. zasada demokratycznego państwa prawnego stanowi jedną z podstaw statusu jednostki w państwie. W orzeczeniu z dnia 24 czerwca 1997 r., a zatem jeszcze przed wejściem w życie Konstytucji z 1997 r., Trybunał Konstytucyjny stwierdził, że „w demokratycznym państwie prawnym powinny być przestrzegane powszechnie uznawane przez społeczność międzynarodową standardy ochrony praw człowieka. W odniesieniu do ochrony życia prywatnego standardy te określają w szczególności: art. 17 Międzynarodowego Paktu Praw Człowieka oraz art. 8 Europejskiej Konwencji o ochronie praw człowieka i podstawowych wolności" ${ }^{35}$. Trudno przecenić orzeczenie Trybunału, który uznał prawo do prywatności za jeden z istotnych elementów demokratycznego państwa prawnego, wskazując jednocześnie na demokratyczne państwo prawne, jako podstawę gwarancji prawa do prywatności. Zasada demokratycznego państwa prawnego obejmuje „swym zakre-

34 Por. J. Barta, R. Markiewicz, op. cit., s. 381.

35 Fakt, iż Powszechna Deklaracja Praw Człowieka i Obywatela z 10 grudnia 1948 r., Międzynarodowy Pakt Praw Obywatelskich i Politycznych, Międzynarodowy Pakt Praw Gospodarczych, Socjalnych i Kulturalnych z 16 grudnia 1966 r. oraz Konwencja o Ochronie Praw i Podstawowych Wolności Człowieka zostały ratyfikowane przez Polskę przed przyjęciem obowiązującej Konstytucji wywarł wpływ na treść regulacji konstytucyjnych w omawianym zakresie. 
sem także pewne treści materialne, w szczególności powiązane z prawami i wolnościami jednostki" ${ }^{\prime 36}$.

Mimo iż $\mathrm{w}$ orzeczeniu dotyczącym prawa do prywatności i ochrony danych osobowych wydanym na podstawie Konstytucji Rzeczypospolitej Polskiej z dnia 2 kwietnia 1997 r. Trybunał Konstytucyjny stwierdził, że „W obecnym stanie prawnym, przyjęty przez konstytucję bardzo szeroki katalog wolności i praw jednostki, obejmujący kategorie normowane w art. 47 i 51 - nie wymaga uzupełniania przez odwoływania się do zawartej w art. 2 konstytucji klauzuli generalnej demokratycznego państwa prawnego" ${ }^{37}$ na gruncie prowadzonych rozważań odwołanie się do zasady demokratycznego państwa prawnego jest uzasadnione.

Bezpośrednią i zapewne podstawową funkcją jaką spełnia w demokratycznym państwie prawnym ochrona danych osobowych jest zabezpieczenie prawa do prywatności. Prawo do ochrony danych osobowych nawiązuje bowiem do prawa do prywatności, co więcej można stwierdzić, że jest jego konsekwencją. Z art. 47 Konstytucji RP wynika prawna ochrona życia prywatnego, rodzinnego i osobistego, z art. 51 natomiast możliwość uchylenia się od odkrywania tych sfer życia poprzez ujawnianie informacji dotyczących osoby. Potwierdzeniem tego jest m.in. stanowisko Trybunału Konstytucyjnego, który stwierdził w jednym z orzeczeń, że ,prawo do prywatności, statuowane w art. 47, zagwarantowane jest m.in. w aspekcie ochrony danych osobowych, przewidzianej w art. 51. Ten ostatni, rozbudowany przepis, odwołując się aż pięciokrotnie do warunku legalności - expressis verbis w ust. 1, 3, 4 i 5 oraz pośrednio przez powołanie się na zasadę demokratycznego państwa prawnego w ust. 2 - stanowi też konkretyzację prawa do prywatności w aspektach proceduralnych" ${ }^{38}$.

Ochrona danych osobowych na płaszczyźnie konstytucyjnej odgrywa niezwykle istotną rolę $\mathrm{w}$ procesie wyznaczania granicy między sferą wpływów państwa a wolnościami i prawami jednostki,

\footnotetext{
${ }^{36}$ Orzeczenie Trybunału Konstytucyjnego K.21/96, OTK ZU 1998/2/23.

37 Orzeczenie TK U5/97.

38 Orzeczenie TK U5/97.
} 
w tym oczywiście sferą jej prywatności. Dlatego też związek ochrony danych osobowych z pojęciem demokratycznego państwa prawnego nie jest przypadkowy. Państwo prawa wyznacza bowiem określone standardy, wśród których jest poszanowanie prywatności jednostki. Nie bez przyczyny ustrojodawca $\mathrm{w}$ art. 51 ust. 2 zapisał, że „,władze publiczne nie mogą pozyskiwać, gromadzić i udostępniać innych informacji o obywatelach niż niezbędne w demokratycznym państwie prawnym". Za informacje niezbędne dla władz publicznych należy uznać informacje, które są niezbędne w granicach kompetencji władz i dla realizacji ich zadań. Informacje mają być zbierane nie ze względu na obywateli, ale ze względu na funkcje i zadania organów władzy publicznej. B. Banaszak i M. Jabłoński definiują informacje niezbędne ,jako te dane, które umożliwiają normalne funkcjonowanie jednostki w zorganizowanym w państwo społeczeństwie i których ujawnienie nie jest naruszeniem sfery prywatności" ${ }^{39}$. Niezależnie od tego, że sformułowanie ,informacje niezbędne" nie jest ostre i budzi wiele wątpliwości interpretacyjnych, bezpośrednie odwołanie do pojęcia demokratycznego państwa prawnego trudno przecenić. Ustrojodawca sformułował bowiem $\mathrm{w}$ omawianym przepisie zasadę ograniczonego przetwarzania danych osobowych, na którą składa się ograniczone pozyskiwanie, gromadzenie i udostępnianie informacji o osobach przez władze publiczne.

\section{GODNOŚĆ CZŁOWIEKA GWARANCJĄ OCHRONY PRAWA DO PRYWATNOŚCI I OCHRONY DANYCH OSOBOWYCH}

Podstawę systemu wolności, praw i obowiązków człowieka i obywatela, w Konstytucji Rzeczypospolitej Polskiej z 2 kwietnia 1997 r.,

${ }^{39}$ B. BanasZaK, M. Jabeoński, Art. 51, [w:] Konstytucje Rzeczypospolitej Polskiej, cit., s. 99. I. LiPowicz, Konstytucyjne podstawy ochrony danych osobowych, [w:] Ochrona danych osobowych $w$ Polsce z perspektywy dziesięciolecia, red. P. FAJGIELSKI, Lublin 2008, s. 49 za dane niezbędne w demokratycznym państwie prawnym uznaje „dane, bez których funkcjonowanie państwa byłoby niemożliwe lub znacznie utrudnione. Nie są to dane, które warto mieć na wszelki wypadek, które dają komfort rządzenia i przewagę informacyjną nad obywatelem". 
tworzącą jednocześnie dyrektywy interpretacyjne, stanowią zasady ogólne (art. 30-37), które sprowadzają się do triady wartości - godności, wolności i równości - na której z kolei oparta jest konstrukcja następnych przepisów. Wśród tych wartości fundamentalne znaczenie posiada godność.

Źródłem prawa do prywatności i prawa do ochrony danych osobowych jest zatem przyrodzona i niezbywalna godność człowieka ${ }^{40}$. Godność człowieka będąca źródłem wszystkich wolności i praw człowieka i obywatela zagwarantowanych w Konstytucji Rzeczypospolitej Polskiej jest ,nienaruszalna, a jej poszanowanie i ochrona jest obowiązkiem władz publicznych" (art. 30). Z zapisu tego wynika fakt, iż wolność sumienia i religii jest przyrodzonym prawem człowieka, które przysługuje mu niezależnie od decyzji kogokolwiek, a zwłaszcza organów władzy państwowej.

Związek ochrony danych osobowych z godnością człowieka nie ogranicza się do stwierdzenia, iż jest ona podstawą wolności i praw zagwarantowanych w ustawie zasadniczej. Relacja ta jest zdecydowanie głębsza. Jak pisze I. Lipowicz „Godność człowieka jako naczelna wartość państwa prawa leży u podstaw ochrony danych osobowych. O ile tortury, poniżające traktowanie, odarcie z intymności to podręcznikowe przykłady naruszenia fizyczności, jego godności w wymiarze fizycznym i psychicznym, o tyle naruszenie prawa do prywatności, intymności to ingerencja w psychikę, która może być trwalszą i boleśniejszą dyskryminacją niż fizyczne tortury. Wystawienie na widok publiczny, przekazanie informacji, naruszenie swoistej ,aury informacyjnej" może być subiektywnie, ale i obiektywnie poniżające, może

40 Trybunał Konstytucyjny stwierdził, że ,,do praw unormowanych w art. 47 i 51 konstytucji, zaliczonych przez ustrojodawcę do kategorii wolności i praw osobistych, w pełni odnosi się konstytucyjne unormowanie zasad ogólnych wolności, praw i obowiązków człowieka i obywatela, zawarte w rozdziale I i II konstytucji. Do zasad tych należy przede wszystkim zaliczenie w art. 5 zapewnienia wolności i praw człowieka i obywatela do podstawowych celów i zadań Państwa Polskiego oraz uznanie w art. 30 przyrodzonej i niezbywalnej godności człowieka za źródło wolności i praw człowieka i obywatela, przy czym godność ta jest nienaruszalna, a jej poszanowanie i ochrona jest obowiązkiem władz publicznych". Orzeczenie TK U5/97. 
prowadzić do trwałego pokrzywdzenia strony ${ }^{41}$ ". Dlatego też - kontynuuje I. Lipowicz - „Państwo ma obowiązek chronić dane swoich obywateli, bo chroni ich godność prowadzącą do ,samodzielnego kształtowania swojego życia" i swojej osobowości"42.

Poszanowanie prawa do prywatności, także poprzez ochronę danych osobowych, może przyczyniać się do poszanowania godności. Zwraca na to uwagę K. Wygoda, który pisze: ,poszanowanie prywatności człowieka poprzez pozostawienie go w spokoju, wyrażające się w nieingerencji (ze strony państwa, ale i innych podmiotów) w pewną określoną (w Polsce także konstytucyjnie) sferę życia jednostki i zabezpieczeniem jej przed nieuprawnionymi działaniami zmierzającymi do naruszenia owej sfery, przyczynia się również do poszanowania godności"43.

\section{UWAGI SYNTETYZUJĄCE}

Problematyka prawa do prywatności i ochrony danych osobowych na gruncie polskiego konstytucjonalizmu stanowi istotne novum. Jest skutkiem rozwoju technik informatycznych i dostosowywania prawa polskiego - w tym prawa konstytucyjnego - do standardów międzynarodowych. Ustrojodawca w art. 47 Konstytucji Rzeczypospolitej Polskiej z dnia 2 kwietnia 1997 r. chroni życie prywatne, rodzinne i osobiste, a w kolejnych przepisach ustawy zasadniczej (zwłaszcza w art. 48-51) rozwija oraz doprecyzowuje gwarancje ochrony prawa do prywatności. Przykładem rozwinięcia i doprecyzowania prawa do prywatności jest ochrona danych osobowych, która została zagwarantowana w art. 51 Konstytucji RP.

$\mathrm{Na}$ konstytucyjne pojęcie prawa do ochrony danych osobowych składają się szczegółowe prawa osób, których dane dotyczą. Na podstawie art. 51 Konstytucji RP można wyróżnić wolność jednostki od ujawnienia informacji dotyczących jej osoby (art. 51 ust. 1), prawa dostępu każdego mieszkańca Polski do dotyczących go dokumentów urzędowych

\footnotetext{
${ }^{41}$ I. Lipowicz, Konstytucyjne, cit., s. 46.

42 I. Lipowicz, Konstytucyjne, cit., s. 46.

${ }^{43}$ K. Wygoda, op. cit., s. 401.
} 
i zbiorów danych (art. 51 ust. 3), żądania sprostowania oraz usunięcia informacji nieprawdziwych, niepełnych lub zebranych w sposób sprzeczny z ustawą (art. 51 ust. 4). Prawa te zostały rozwinięte i doprecyzowane przez ustawodawce w rozdziale 4 przywoływanej ustawy o ochronie danych osobowych (art. 32-35).

Problematyka związku ochrony danych osobowych $\mathrm{z}$ prawem do prywatności wiąże się przede wszystkim z materialnym związkiem istniejącym w konstrukcji prawnej stworzonej przez polskiego ustrojodawcę. Wskazuje jednocześnie na kapitalne znaczenie prawa do prywatności w procesie stosowania przepisów chroniących dane osobowe. Stanowisko doktryny nie jest w omawianym zakresie jednolite, dlatego też $\mathrm{w}$ niniejszym opracowaniu zostało również uwzględnione stanowisko, według którego ochrona danych osobowych nie łączy się z prawem do prywatności.

Gwarantem prawa do prywatności i ochrony danych osobowych jest demokratyczne państwo prawa. Na gruncie obowiązującej Konstytucji nie ma potrzeby wyprowadzania ochrony danych osobowych z zasady państwa prawnego (jak to czynił Trybunał Konstytucyjny przed wejściem w życie Konstytucji z dnia 2 kwietnia 1997 r.), niemniej jednak - zdaniem autora - zasada, będąc fundamentalną zasadą ustrojowa, stanowi także jedną z podstaw statusu prawnego jednostki w państwie, a zatem w sposób pośredni wpływa na ochronę danych osobowych. Stanowisko takie uzasadnia również odwołanie się przez ustrojodawcę w art. 51 ust. 2 do zasady demokratycznego państwa prawnego w odniesieniu do szczegółowej zasady pozyskiwania, gromadzenia i udostępniania informacji o obywatelach przez władze publiczne.

Konstytucyjny status jednostki w państwie opiera się na triadzie wartości, do których ustrojodawca zaliczył godność (art. 30), wolność (art. 31) i równość (art. 32). Na niej jest oparta konstrukcja następnych przepisów, w tym prawa do prywatności (art. 47) i prawa do ochrony danych osobowych (art. 51). Wśród zasad przewodnich statusu jednostki fundamentalne znaczenie posiada przyrodzona godność człowieka, która jest źródłem prawa do prywatności i prawa do ochrony danych osobowych, co zostało potwierdzone w orzeczeniach Trybunału Konstytucyjnego. 


\section{Personal Data Protection as Part of the Right to Privacy}

\section{Summary}

The issues related to the right to privacy and personal data protection are a new important area for the constitutional studies in Poland. Their emergence owes much to the development of information technology and the adjustment of Polish law, including constitutional law, to international standards. Under the Constitution of the Republic of Poland of 2 April 1997, personal protection is seen as part of the right to privacy. The following issues have become the subject of the academic research: the constitutionalization of personal data protection, constitutional rights of identifiable persons, the relation of personal data and the right to privacy, the democratic state under the rule of law as the guarantor of the right to privacy and personal data protection, as well as human dignity as the basis of this right. 